\title{
Factors Influencing Chinese Firms' Decision Making in Foreign Direct Investment in Thailand
}

\author{
Xiao Ling Huang, Athapol Ruangkanjanases, and Chenin Chen
}

\begin{abstract}
The objectives of this study were: 1) to explore factors that have positive and significant influence on Chinese firms' decision making in FDI in Thailand, 2) to identify factors that can be the significant predictor of Chinese FDI in Thailand, and 3) to provide recommendations for Thai government and policy makers in order to improve Thailand's investment climate with the intention to maintain existing Chinese FDI and attract more potential investors from China.

The researchers utilized the FDI model which consists of 6 factors which are $P F$ (political factors), $G F$ (government regulations and laws factors), LF (location factors), MF (market Factors), SF (social and cultural factors), and FF (financial factors). This model was formulated from the OLI and PESTEL framework.

Research findings showed that there were only two factors, location factors and Social and cultural factors, having positive and significant correlation with Chinese FDI. However, none of any factors had predictive power on Chinese FDI. The findings indicated that investment motivations and Chinese cultural context "guan xi" played a very important role to influence Chinese decision-makers in FDI in Thailand.
\end{abstract}

Index Terms-FDI, eclectic paradigm, OLI, entry modes, PESTEL, Chinese, Thailand.

\section{INTRODUCTION}

Global FDI trends: The changing global economic and political environment handled to a dramatic increase in international activities by multinational enterprises (MNEs) over the last three decades. MNEs' international behaviors have played an essential role in promoting and shaping the patterns of economic development, cross-national flow of goods, capital, and technology [1], [2]. FDI means higher exports, accessing to international markets and international currencies, being an important source of financing, substituting bank loans, contributing to foreign exchange earnings, creating employment, increasing incomes and so forth. FDI plays an important role in the international economy after the Second World War; it is an important element of economic development in all countries. All these activities of MNEs are strongly affected by means of their foreign direct investment (FDI) decisions.

FDI in Thailand: Thailand is used to be named as the Newly Industrializing country (NIC) in 1990s. There was a large increase in FDI at the end of the 1980s until the late 1990s (before the financial crisis in 1997). After the

Manuscript received July 4, 2014; revised August 25, 2014.

Xiao Ling Huang was with Chulalongkorn Business School, Chulalongkorn University, Thailand (e-mail: ashima583@hotmail.com)

Athapol Ruangkanjanases and Chenin Chen are with Chulalongkorn Business School, Chulalongkorn University, Thailand (e-mail: athapol@cbs.chula.ac.th, chenin.c@chula.ac.th). financial crisis in 1997, Thailand's economy had dropped but recovered fully from that crisis with its first fiscal surplus in 2003.

FDI contributed a lot to Thailand's economic growth and development. The FDI inflow into Thailand has accelerated rapidly and it will play an increasingly important role in Thailand's economy in the future. With the openness of AEC in 2015, the competition will be fierce among member countries. In order to attract more FDI, Thai government should put more effort on creating a better investment climate.

OFDI (Outward Foreign Direct Investment) of China: Chinese "Go-out strategy" has embraced its 10th anniversary in 2010. In the past decade, Chinese companies had been picking up their paces of going global and increasing their overseas investments at both of developed and developing countries. Thailand possesses a strategic position in this region, although FDI from China is not the main source for Thailand so far, there is a big potential opportunity for Thailand to be an important FDI destination of Chinese companies. More and more Chinese firms have been expanding their investment rapidly in Thailand; at the same time, abundant of FDI from China are seeking good investment destinations.

In order to maintain and enlarge the re-investment of the existing Chinese FDI, furthermore, to attract more Chinese companies to invest in Thailand. Thai government and policy makers should put more effort on its governance in inward FDI.

\section{LITERATURE REVIEW}

\section{A. Foreign Direct Investment (FDI)}

Hymer's path-breaking study [3] is the first explanation of FDI activities, as a means of transferring knowledge and other intangible firm assets to produce abroad. There are many definition for the FDI, for statistical purposes, the United Nations defines FDI as an equity stake of $10 \%$ or more in foreign-based enterprises, with the higher percentage invested in a foreign firm, it is possible for the investors to exercise management control right, namely, have absolute authority to appoint key manager and establish control mechanisms.

The International Monetary Fund [4] defines FDI as a category of international investment that reflects the objectives of a resident in one country (the direct investor) obtaining a lasting interest in an enterprise resident in another economy (the direct investment enterprises or host economy). The lasting interest implies the existence of a long-term relationship between the direct investors and the direct investment enterprise, the significant degree of 
influence by the investors and the direct investment enterprise, and significant degree of influence by the investor on the management of the enterprise. The ownership of at least $10 \%$ of the ordinary shares or voting stock is the criterion for the existence of a direct investment relationship, ownership of less than $10 \%$ is considered a portfolio investment. FDI comprises not only mergers, takeover, acquisitions (Brownfield Investment) and new investment (Greenfield Investment), but also reinvested earning and loans similar capital transfer between parents and affiliates [5].

From a macroeconomic point of view, FDI is a particular form of capital flows across border from home countries to host countries, which are found in the balance of payment. The variable of interest is: capital flows and stocks, revenues obtained from investments, from microeconomic point of view, it tries to explain the motivations for investment across national boundaries of the investor, it also examines the consequences to investor, to the home and host country, of the operations of the multinationals rather than investment flows and stock [6]. According to Kumar [7] "FDI usually flows as a bundle of resources including, capital, production technology, organizational and managerial skills, marketing, know-how, and even market access through the marketing networks of multinational enterprises (MNEs) who undertake FDI" these skillresources tend to spill over to domestic enterprises in the host country. Therefore, FDI is expected to contribute more economic growth than domestic investment in the host country. FDI become an important source of private external financing for developing countries with minimal capital.

\section{B. General Motivations of FDI}

A better understanding of MNEs' investment motivations would also benefit policy makers to make more effective and proper policies to attract more inward FDI, which requires knowledge and understanding of the drivers of the MNEs' investment, since investment driven by different motivations require different policy responses [8]. Dunning [9] classified the various motivations under five major categories: market seeking, resource seeking, efficiency seeking, export seeking and competitive strategic seeking.

\section{Eclectic Paradigm (OLI Framework) of Dunning}

Dunning developed this comprehensive framework, which integrates ownership, location, and internalization advantages. It is one of the first rigorous attempts to understand, from an integrative and general point of view, the determinants that drive MNE managers from a specific home country to undertake FDI in different groups of host countries. More specifically, it is usually argued that the engagement of any enterprise in international production will depend on the presence of these three groups of advantages, with each group of variables acting interdependently [9].

The OLI paradigm is a mix of various theories of foreign direct investment, that concentrating on various questions: $\mathrm{FDI}=\mathrm{O}+\mathrm{L}+\mathrm{I}$.

O stands for Ownership specific advantage or FSA-Firm Specific Advantages. There are three types of specific advantages: a) Monopoly advantages in the form of privileged access to markets through ownership of natural limited resources, patents, trademarks; b) Technology, knowledge broadly defined so as to contain all forms of innovation activities; c) Economies of large size such as economies of learning, economies of scale and scope, greater access to financial capital.

L stands for Location specific advantage. The specific location advantages of each country can be divided into three categories: a) E-Economic advantages consist of quantitative and qualitative factors of production, costs of transport, telecommunication, market size etc. b) P- Political Advantages include the common and specific government policies that affect FDI flows, intra-firm trade and international production. c) S-Social, cultural advantages include geographic distance between the home countries, language and cultural diversity, general attitude towards foreigner and the overall position towards free enterprises.

I stands for Internalization incentive advantage. It is another great advantage associated with FDI in terms of the ability to replace the external market relationship with one firm (the MNE) owning, controlling, and managing activities in two or more countries. Internalization is important because of significant imperfections in international market transactions. The institution-based view suggests that markets are governed by rules, regulations, and norms that are designed to reduce uncertainties. Uncertainties introduce transaction costs (costs associated with doing business); International transaction costs tend to be higher than domestic transaction costs. Because laws and regulations are typically enforced on a nation-state basis, enforcement can be problematic at the international level.

\section{PESTEL Analysis}

PESTEL analysis stands for "Political, Economic, Social, Technological, Legal, and Environmental analysis" and describes a framework of macro-environment factors used in the environment scanning component of strategic management. It is a part of the external analysis when conducting a strategic analysis or doing market research, and gives an overview of the different macro-environmental factors that the company has to take into consideration. It is a useful strategic tool for understanding market growth or decline, business position, potential and direction for operations. It is really essential and necessary to do PESTEL analysis in the FDI decision-making process. All of factors in the PESTLE analysis are basic information need to be considered before conducting FDI in the host country.

\section{RESEARCH METHODOLOGY}

\section{A. Conceptual Framework}

The conceptual framework of this study was based on the literature review and related studies previously stated. This study mainly based on OLI framework of Dunning [9] which was widely used in the factors to influence FDI to the host country. In this study the researchers mainly focus on the "location specific advantages of host country" as an external factor to impact the decision-making of Chinese firms when they are conducting FDI in Thailand. PESTEL framework is a useful method to analyze the investment climate of Thailand. Combining the "OLI" and "PESTEL" 
frameworks and formulating the research model of this study, this model also be utilized in the study "A comparative analysis of the US and Japan FDI in Thailand" of Boonlua [10].The model is:

\section{$\mathrm{FDI}=\mathrm{PF}+\mathrm{GF}+\mathrm{LF}+\mathrm{MF}+\mathrm{SF}+\mathrm{FF}$}

where:

FDI represents Chinese FDI

$\mathrm{PF}$ is politic factors

GF is government factors

$\mathrm{LF}$ is location factors

MF is market factors

$\mathrm{SF}$ is social and cultural factors

FF is financial factors

Thirty six variables in the questionnaire were derived from these 6 factors; a nationwide mail survey were undertaken among top and middle management (CEO, senior and middle managers) in either joint ventured or wholly owned subsidiaries of Chinese firms in Thailand. These top and middle managers are in good position to know about various internal and external considerations behind the choice of FDI in Thailand [11].

Based on the conceptual framework, hypotheses of this study were as follows:

H1: These 6 aspects (political factors, government regulations and laws factors, location factors, market factors, social and cultural factor and financial factors) have positive and significant relationship with Chinese FDI in Thailand.

H2: These 6 factors (political factors, regulation factors, location factors, market factors, social and cultural factor and financial factors) will be the significant predictor of Chinese FDI in Thailand.

\section{B. Data Collection}

Questionnaire survey was the main method to collect the primary source of data for this research. It was comprised of four parts: general company information, factors influencing on decision-making of Chinese FDI in Thailand, overall assessment on satisfaction degree and willingness to reinvest in Thailand, and recommendations and suggestions. In 2012, there were 143 Chinese companies having records at the Chinese Embassy in Thailand. Therefore, the researchers used 143 as a population of this study. Using 95 percent confidence level with sampling error of 5 percent based on Yamane [12], sample size was 105 companies. The survey was conducted between September and November 2012. Total of 66 completed questionnaires were returned. Therefore the sampling error of 7 percent was applied instead of 5 percent as originally planned.

\section{Measures}

This study used a five-point Likert scale, ranging from the Most Important (5) to the Least Important (1), to measure the importance degree of each factor influencing on the decision-making of Chinese investors in Thailand; and ranging from the Strongly Agree (5) to the Strongly Disagree (1), to measure the satisfaction degree and willingness to re-invest in Thailand. All primary data from the completed questionnaires were coded and keyed in.

\section{Independent Variables}

The independent variables consisted of 36 factors derived from 6 aspects: $1 \mathrm{PF}$ (Political factors) $2 \mathrm{GF}$ (Government regulations and law factors) $3 \mathrm{LF}$ (Location factors) $4 \mathrm{MF}$ (Market factors) 5 SF (Social and cultural factors) 6 FF (Financial factors). These 6 aspects were hypothesized to have significant impact on dependent variables. Totally 36 factors were derived from 6 aspects related to the investment climate of Thailand, details are as follows;

1) PF: political factors: 1) political stability, 2) Government transparency, 3) Openness of the country, 4) Openness of the Country, 5) Work efficiency of Government, 6) Government reliability, 7) FDI policies continuity.

2) GF: government regulations and law factors: 1) FDI tax incentives, 2) Strong law enforcement and administration, 3) Foreign equity restrictions, 4) Limitation of land ownership by foreign entities, 5) The efficiency of company registration processes, 6) The efficiency of visa and work permit application processes.

3) LF: location factors: 1) Abundant natural resources, 2) Strategic location in ASEAN countries, 3) Sophisticated infrastructure, 4) World-class industrial estates, 5) Upgrade communication and IT networks, 6) Promoted industrial zones.

4) MF: market factors: 1) Market size, 2) Market growing potential, 3) Openness of the market, 4) Cost-effective labor force, 5) Abundant supply of raw material, 6) Favorable market competition.

5) SF: social and cultural factor consists of: 1) Foreign friendly and harmonious society, 2) Good reputation for safety, 3) Liberty of believe, 4) Higher education level of people, 5) Affordable world-class healthcare and international school conditions, and 6) Good living condition of expats.

6) FF: Financial factors: 1) Stability of exchange rate, 2) The proper level of interest rate, 3) The proper level of inflation rate, 4) Accessible to capital market, 5) Updated banking system, and 6) Reasonable cost of doing business.

The overall assessment on satisfaction degree and willingness to re-invest in Thailand is to clarify how much the Chinese investors satisfied with the investment climate of Thailand and if they are willing to re-invest in Thailand in the future.

\section{E. Dependent Variable}

The dependent variable of this study is the satisfaction level of Chinese firms in Thailand. This dependent variable was assumed to be influenced by all of the above independent variables.

\section{DATA ANALYSIS}

The data analysis was carried out by using SPSS software version 19 to determine descriptive statistics which consisted of frequency, percentage, mean, and standard deviation that were used to report information about company profiles. The researchers also used inferential statistics; multiple regression and correlation analysis, to test 
the hypotheses and identify which external factors, from the conceptual framework, have a significant influence on decision-making of Chinese FDI in Thailand.

The analysis results were demonstrated by the statistical analysis program. All the primary data from total 66 questionnaires had been analyzed, and the findings were classified into 3 main parts as follows;

1) General company information of the respondents and sources of the information utilized by Chinese firms to recognize the investment opportunities in Thailand.

2) The mean and standard deviation of all variables.

3) Hypothesis testing: Analysis of factors influencing on decision-making in FDI in Thailand to Chinese firms.

\section{A. Part 1: General Company Information}

This section utilized the descriptive statistics to describe a series of information both of subsidiary and parent company, such as: FDI entry model, allocation of shares, the field and motivation of new investment in Thailand, and the ownership, company scale of parent company in China. The details are shown in Table I.

TABLE I: NUMBERS AND PERCENTAGES ABOUT INVESTMENT INFORMATION $(N=66)$

\begin{tabular}{lrr}
\hline Investment information & Numbers & Percentages \\
1. FDI entry mode & & \\
1.1 Greenfield Investment & 40 & 60.61 \\
1.2 Merger and Acquisition & 7 & 10.61 \\
1.3 Joint Venture & 19 & 28.79 \\
\hline 2. Allocation of the investment shares & & \\
2.1 100\% shareholder & 39 & 59.09 \\
2.2 Majority shareholder $\quad$ & \\
$\quad$ more than 50\% and less than 100\%) & 8 & 12.12 \\
2.3. Minority shareholder (less than 50\%) & 19 & 28.79 \\
\hline 3. Main investment fields & & \\
3.1 Manufacturing & 43 & 65.15 \\
3.2 Trading & 9 & 13.64 \\
3.3 Transportation & 3 & 4.55 \\
3.4 Construction & 2 & 3.03 \\
3.5 Banking & & 3.03 \\
3.6 Software and IT Services & & 1.52 \\
3.7 Real Estate & & 1.52 \\
3.8 Farming, Forestry, Animal Husbandry, & 1 & 1.52 \\
Fisheries & & \\
3.9 Others & & \\
\hline & & \\
\hline
\end{tabular}

\section{Ownership of the parent company \\ in China}

4.1 Stated-owned company $\quad 23 \quad 34.85$

\begin{tabular}{lll}
4.2 Private company & 43 & 65.15 \\
\hline
\end{tabular}

\section{Scale of parent company in China}

\begin{tabular}{lll} 
5.1 Large Size Company & 41 & 62.12 \\
5.2 Middle Size Company & 13 & 19.70 \\
5.3 Small Size Company & 12 & 18.18 \\
\hline
\end{tabular}

\section{Investment motivation}

6.1 Marketing Seeking

6.2 Natural Resource Seeking

6.3 Efficiency Seeking

6.4 Export Seeking

\section{B. Part 2: The Mean and Standard Deviation of All Variables}

As stated in the previous sections, 36 independent variables used in this study were derived from 6 aspects: 1) PF (political factors), 2) GF (government factors), 3) $\mathrm{LF}$ (location factors), 4) MF (market factors), 5) SF (social and cultural factors), and 6) FF (financial factors). The dependent variable was FDI inflow in Thailand of Chinese firms which was presented by overall Chinese investors' satisfaction towards investment climate of Thailand and the willingness to re-invest in Thailand, which was assumed to be influenced by all of the 36 independent variables. All the related statements derived from political factors were presented in Table II.

According to the results showed in Table II, the importance degree of the respondents for political factors was in more important degree with the mean of 3.89 $(S D=0.62)$. The results showed that political stability had the highest average scores (Mean=4.18, $\mathrm{SD}=0.959)$, responding the most import factor among all other items, while government transparency was in important degree with the lowest average scores (mean=3.35, $\mathrm{SD}=1.3$ ).

TABLE II: MEAN AND IMPORTANCE DEGREE OF POLITICAL FACTORS

\begin{tabular}{lccl}
\multicolumn{1}{c}{ Political factors } & Mean & $\begin{array}{c}\text { Std. } \\
\text { Deviation }\end{array}$ & $\begin{array}{c}\text { Degree of } \\
\text { Importance }\end{array}$ \\
\hline \hline $\begin{array}{l}\text { 1.Political stability } \\
\text { 2.Government } \\
\text { transparency }\end{array}$ & 4.18 & 0.959 & $\begin{array}{l}\text { More important } \\
\text { Important }\end{array}$ \\
$\begin{array}{l}\text { 3.Openness of the } \\
\text { Country }\end{array}$ & 3.35 & 1.3 & More important \\
$\begin{array}{l}\text { 4.Work efficiency of } \\
\text { government }\end{array}$ & 3.77 & 0.941 & More important \\
$\begin{array}{l}\text { 5.Government reliability } \\
\text { 6.FDI policies continuity }\end{array}$ & 3.95 & 0.867 & $\begin{array}{l}\text { More important } \\
\text { More important }\end{array}$ \\
\hline Political factors & $\mathbf{3 . 8 9}$ & $\mathbf{0 . 6 2}$ & $\begin{array}{l}\text { More } \\
\text { important }\end{array}$ \\
\hline \hline
\end{tabular}

TABLE III: MEAN AND IMPORTANCE DEGREE OF GOVERNMENT FACTORS $(N=66)$

\begin{tabular}{|c|c|c|c|}
\hline Government Factors & Mean & $\begin{array}{c}\text { Std. } \\
\text { Deviation }\end{array}$ & $\begin{array}{c}\text { Degree of } \\
\text { importance }\end{array}$ \\
\hline 1.FDI Tax Incentives & 3.94 & 1.006 & More important \\
\hline 2.Law Enforcement and & 3.85 & 0.864 & More important \\
\hline $\begin{array}{l}\text { Administration } \\
\text { 3.Foreign Equity Restrictions }\end{array}$ & 3.64 & 1.062 & More important \\
\hline $\begin{array}{l}\text { 4.Land Ownership by Foreign } \\
\text { Entities }\end{array}$ & 3.59 & 1.081 & More important \\
\hline $\begin{array}{l}\text { 5.The Efficiency of Company } \\
\text { Registration Processes }\end{array}$ & 3.14 & 1.051 & Important \\
\hline $\begin{array}{l}\text { 6.The Efficiency of Visa and } \\
\text { Work Permit Application } \\
\text { Processes }\end{array}$ & 3.27 & 1.089 & Important \\
\hline $\begin{array}{l}\text { Government Regulations } \\
\text { and Law Factors }\end{array}$ & 3.57 & 0.649 & $\begin{array}{l}\text { More } \\
\text { Important }\end{array}$ \\
\hline
\end{tabular}

The mean and importance degree of government factors are showed in Table III. Findings showed that the importance degree of the respondents for government regulations and laws factors was in more important degree with the mean of $3.57(\mathrm{SD}=0.649)$. The results showed that FDI tax incentives had the highest average scores (Mean=3.94, SD=1.006), responding the most import factor 
among all other items, while the efficiency of company registration processes was in important degree with the lowest average scores (mean $=3.14, \mathrm{SD}=1.051)$.

TABLE IV: MEAN AND IMPORTANCE DEGREE OF GOVERNMENT FACTORS

\begin{tabular}{|c|c|c|c|}
\hline \multicolumn{4}{|c|}{$(N=66)$} \\
\hline Location factors & Mean & $\begin{array}{c}\text { Std. } \\
\text { Deviation }\end{array}$ & $\begin{array}{l}\text { Degree of } \\
\text { importance }\end{array}$ \\
\hline $\begin{array}{l}\text { 1.Abundant natural } \\
\text { resources }\end{array}$ & 3.05 & 1.364 & Important \\
\hline $\begin{array}{l}\text { 2.Strategic location } \\
\text { in ASEAN }\end{array}$ & 3.5 & 1.113 & More important \\
\hline $\begin{array}{l}\text { 3.Sophisticated } \\
\text { infrastructure }\end{array}$ & 3.56 & 0.963 & More important \\
\hline $\begin{array}{l}\text { 4.World-class } \\
\text { industrial estates }\end{array}$ & 3.11 & 1.04 & Important \\
\hline $\begin{array}{l}\text { 5.Upgraded } \\
\text { communication and } \\
\text { IT networks. }\end{array}$ & 3.26 & 1.1 & Important \\
\hline $\begin{array}{l}\text { 6.Promoted } \\
\text { industrial zones }\end{array}$ & 2.68 & 1.242 & Important \\
\hline Location factors & 3.19 & 0.769 & Important \\
\hline
\end{tabular}

Table IV showed that overall importance degree of the respondents for location factors was in important degree with the mean of $3.19 \quad(\mathrm{SD}=0.769)$. Sophisticated infrastructure had the highest average scores (Mean=3.56, $\mathrm{SD}=0.963$ ), while promoted industry zones had the lowest average scores (mean $=2.68, \mathrm{SD}=1.242$ ).

According to the results showed in the Table $\mathrm{V}$, the importance degree of the respondents for market factors was in more important degree with the mean of 3.55 $(\mathrm{SD}=0.802)$. The results showed that market growing potential had the highest average scores (Mean=3.82, $\mathrm{SD}=1.201$ ) while cost-effective labor force was in important degree with the lowest average scores (mean=3.27, $\mathrm{SD}=1.144)$.

\begin{tabular}{lccc}
$\begin{array}{l}\text { TABLE V: MEAN AND IMPORTANCE DEGREE OF MARKET FACTORS }(N=66) \\
\text { Market factors }\end{array}$ & Mean & $\begin{array}{c}\text { Std. } \\
\text { Deviation }\end{array}$ & $\begin{array}{c}\text { Degree of } \\
\text { importance }\end{array}$ \\
\hline \hline $\begin{array}{l}\text { 1.Market size } \\
\text { 2.Market growing } \\
\text { potential }\end{array}$ & 3.64 & 1.172 & $\begin{array}{c}\text { More important } \\
\text { More important }\end{array}$ \\
$\begin{array}{l}\text { 3.Openness of the } \\
\text { market }\end{array}$ & 3.74 & 1.012 & More important \\
$\begin{array}{l}\text { 4.Cost-effective } \\
\text { labor force }\end{array}$ & 3.27 & 1.144 & Important \\
$\begin{array}{l}\text { 5.Abundant supply } \\
\text { of raw material }\end{array}$ & 3.23 & 1.31 & Important \\
$\begin{array}{l}\text { 6.Favorable market } \\
\text { competition }\end{array}$ & 3.62 & 1.049 & More important \\
\hline \begin{tabular}{l} 
Market factors \\
\hline \hline
\end{tabular} & $\mathbf{3 . 5 5}$ & $\mathbf{0 . 8 0 2}$ & More important \\
\hline
\end{tabular}

Table VI showed the importance degree of the respondents for social and cultural factors. Overall scores was in important degree with the mean of 3.28 $(\mathrm{SD}=0.7191)$. The results showed that foreign friendly and harmonious society had the highest average scores (Mean=4.03, $\mathrm{SD}=0.992$ ), responding the most import factor among all other items, while affordable world-class healthcare and international school conditions was in important degree with the lowest average scores (Mean=2.92, SD=1.100).
TABLE VI: MEAN AND IMPORTANCE DEGREE OF SOCIAL AND CULTURAL

\begin{tabular}{lccc} 
& FACTORS $(N=66)$ & \\
\hline $\begin{array}{l}\text { Social and Cultural } \\
\text { Factors }\end{array}$ & Mean & $\begin{array}{c}\text { Std. } \\
\text { Deviation }\end{array}$ & $\begin{array}{c}\text { Degree of } \\
\text { Importance }\end{array}$ \\
\hline \hline $\begin{array}{l}\text { 1. Foreign friendly } \\
\text { and harmonious } \\
\text { society }\end{array}$ & 4.03 & 0.992 & More important \\
$\begin{array}{l}\text { 2. Good reputation } \\
\text { for safety }\end{array}$ & 3.92 & 0.829 & More important \\
$\begin{array}{l}\text { 3. Liberty of } \\
\text { believes }\end{array}$ & 2.83 & 1.197 & Important \\
$\begin{array}{l}\text { 4. The education } \\
\text { level of labor force }\end{array}$ & 3.33 & 0.883 & Important \\
$\begin{array}{l}\text { 5. Affordable } \\
\text { world-class } \\
\text { healthcare and } \\
\text { international school } \\
\text { conditions }\end{array}$ & 2.64 & 1.062 & Important \\
$\begin{array}{l}\text { 6. Good living } \\
\text { condition of expats }\end{array}$ & 2.92 & 1.1 & Important \\
\hline $\begin{array}{l}\text { Social and } \\
\text { cultural factors }\end{array}$ & $\mathbf{3 . 2 8}$ & $\mathbf{0 . 7 1 9 1}$ & Important \\
\hline \hline
\end{tabular}

Results in the Table VII indicated that the overall importance degree of the respondents for financial factors was more important with the mean of $3.5(\mathrm{SD}=0.767)$. The stability of exchange rate had the highest average scores (Mean=3.88, SD=0.851while accessible to capital market had the lowest average scores (mean=3.18, $\mathrm{SD}=1.094$ ).

\begin{tabular}{|c|c|c|c|}
\hline \multirow[t]{2}{*}{ Financial factors } & Mean & Std. & Importance degree \\
\hline & \multicolumn{3}{|c|}{ Deviation } \\
\hline $\begin{array}{l}\text { 1.Stability of } \\
\text { exchange rate }\end{array}$ & 3.88 & 0.851 & More important \\
\hline $\begin{array}{l}\text { 2. The proper level } \\
\text { of interest rate }\end{array}$ & 3.52 & 0.98 & More important \\
\hline $\begin{array}{l}\text { 3.The proper level } \\
\text { of inflation rate }\end{array}$ & 3.5 & 1.011 & More Important \\
\hline $\begin{array}{l}\text { 4.Accessible to } \\
\text { capital market }\end{array}$ & 3.18 & 1.094 & Important \\
\hline $\begin{array}{l}\text { 5.Updated Banking } \\
\text { system }\end{array}$ & 3.3 & 1.136 & Important \\
\hline $\begin{array}{l}\text { 6.Low cost of } \\
\text { doing business }\end{array}$ & 3.64 & 0.971 & More Important \\
\hline Financial factors & 3.5 & 0.767 & More Important \\
\hline
\end{tabular}

\section{Part 3: Hypothesis Testing \\ 1) Correlation analysis}

H1: These 6 aspects (political factors, government regulations and laws factors, location factors, market factors, social and cultural factor and financial factors) have positive and significant relationship with Chinese FDI in Thailand.

For hypotheses testing, Pearson's product moment correlation was performed to identify the relationships between 6 independent variables (political factors, government regulations and laws factors, location factors, market factors, social and cultural factor and financial factors) with the dependent variable (Chinese FDI) for testing hypothesis $1(\mathrm{H} 1)$. 


\begin{tabular}{|c|c|c|c|c|c|c|c|}
\hline variables & FDI & 1.PF & 2.GF & 3. LF & 4.MF & 5.SF & 6.FF \\
\hline FDI Pearson correlation & 1 & .189 & .054 & $.302 *$ & .104 & $.268 *$ & .09 \\
\hline Sig.(2-tailed) & & .128 & .669 & .014 & .406 & .03 & .471 \\
\hline 1.PF Pearson correlation & & 1 & $.564 * *$ & $.428 * *$ & $.383 * *$ & $.487 * *$ & $.361 * *$ \\
\hline Sig.(2-tailed) & & & .000 & .000 & .001 & .000 & .003 \\
\hline 2.GF Pearson correlation & & & 1 & $.452 * *$ & $.462 * *$ & $.478 * *$ & $.580 * *$ \\
\hline Sig.(2-tailed) & & & & .000 & .000 & .000 & .000 \\
\hline 3.LF Pearson correlation & & & & 1 & $.411 * *$ & $.638 * *$ & $.370 * *$ \\
\hline Sig.(2-tailed) & & & & & .000 & .000 & .000 \\
\hline 4.MF Pearson correlation & & & & & 1 & $.369 * *$ & $.416^{* *}$ \\
\hline Sig.(2-tailed) & & & & & & .002 & .001 \\
\hline 5. SF Pearson correlation & & & & & & 1 & $.592 * *$ \\
\hline Sig.(2-tailed) & & & & & & & .000 \\
\hline $\begin{array}{l}\text { 6. FF Pearson correlation } \\
\text { Sig.(2-tailed) }\end{array}$ & & & & & & & 1 \\
\hline
\end{tabular}

Table VIII displayed the correlation coefficients between 36 independent variables derived from these 6 factors with dependent variable represented the FDI inflow assessment in Thailand of Chinese firms. From the analysis results found that just two factors: 1$)$ location factors $(r=0.302, p=0.014)$ and 2) social factors $(r=0.268, p=0.030)$ have the positive correlation at the 0.05 level of significance, Therefore, hypothesis 1 was partly confirmed, but as the correlation coefficients are less than 0.5 , that means these two factors have weak linear relationship with Chinese FDI in Thailand.

\section{Multiple Regression Analysis}

$\mathrm{H} 2$ : These 6 factors (political factors, regulation factors, location factors, market factors, social and cultural factor and financial factors) will be the significant predictor of Chinese FDI in Thailand.

Multiple regressions was used to identify the predictive power of these 6 factors influencing on the overall Chinese FDI in Thailand for testing the hypothesis $2(\mathrm{H} 2)$ of the study. Stepwise multiple regression analysis was used in this study to explore which 6 factors can predict the FDI inflow in Thailand from China. From the analysis results presented in Table IX showed that all 6 factors have no significant influence on Chinese FDI in Thailand. Therefore, Hypothesis 2 was rejected.

\begin{tabular}{lccccc}
\multicolumn{6}{c}{ TABLE IX: SuMMARY OF REGRESSION COEFICIENTS $(N=66)$} \\
\hline \multicolumn{3}{l}{$\begin{array}{l}\text { Unstandardized Std } \\
\text { Coefficients Error }\end{array}$} & \multicolumn{5}{c}{$\begin{array}{l}\text { Standardized } \\
\text { Coefficients }\end{array}$} \\
& $B$ & & $\beta$ & $t$ & Sig \\
\hline \hline (Constant) & 3.174 & 0.499 & & 6.361 & 0 \\
PF & 0.115 & 0.147 & 0.123 & 0.784 & 0.436 \\
GF & -0.16 & 0.156 & -0.18 & -1.04 & 0.303 \\
LF & 0.183 & 0.126 & 0.243 & 1.457 & 0.15 \\
MF & -0 & 0.105 & -0.01 & -0.04 & 0.971 \\
SF & 0.129 & 0.151 & 0.16 & 0.854 & 0.397 \\
FF & -0.02 & 0.129 & -0.03 & -0.18 & 0.855 \\
\hline \hline
\end{tabular}

Note: Dependent variable: Chinese FDI in Thailand

\section{CONCLUSION AND Discussion}

This study found that only location factors and social and cultural factors had positive and significant correlation with Chinese FDI in Thailand. There are several reasons may explain why this two factors significantly influence on Chinese FDI.

The reasons to support the first factor, Location advantages of Thailand, could be summarized as follows;

1) Geographical proximity between China and Thailand: The close geographic location between two countries facilitates the efficiency of supply chains and save the logistics cost.

2) Strategic location in ASEAN of Thailand: Thailand locates in the center of Southeast Asia, which provides many advantages in terms of logistics and supply chain management.

3) Sophisticated infrastructures: Comparing with other ASEAN countries, the software and hardware infrastructure is much better than many other ASEAN countries.

4) Good trade relationships with US and European Countries: As the good reputation and image of Thai products in the world market, Thailand always maintains a good trade relationship with US and Countries. The country of origin changed from "Made in China" to "Made in Thailand" will helpfully assist Chinese firms to circumvent the trade barriers of US and European countries.

For the second factor, Social and cultural advantages of Thailand, the reasons to support this factor are listed as follows;

1) Good relationship between Thailand and China: from the history perspective, China and Thailand have no wars or big conflicts. Both governments and people of two countries always try to keep positive relationship. Two countries share the similar culture background as Asian country; people can get better communication than people from western countries.

2) Being friendly and harmonious Thai society: As the 
"Kingdom of Smile", Thailand has very good reputation on Thai people's hospitality and friendly. Under the Buddhism background, most Thai people are very nice, the whole society is harmonious. This is very important factor to influence the decision-making in FDI in Thailand to Chinese firms.

3) Good reputation on safety and living conditions: Comparing with other ASEAN countries, Thailand has a better reputation on safety issues. Thailand is a famous tourism destination in the world, better natural environment and living conditions are also an important factor to impact the decision-making of Chinese investors.

Regarding other factors (political factors, government regulations and laws factors, market factors, financial factors), they were theoretically assumed to have positive and significant relationship with FDI decision-making of investors. However, because of the diversity of industries, company capacities, company background, investment motivation and so forth, there is no fixed model or theory to explain all FDI cases in different countries and areas.

According to results from the multiple regression analysis, there were no factors having predictive power on Chinese FDI. There are three reasons that can partly explain as follows;

1) Internal push factors of these Chinese firms played more important role in the FDI decision-making in Thailand: Export-seeking is the major investment motivation of these 66 Chinese firms; the internal motivation push Chinese firms go out to seek investment opportunities. Southeast Asia is a very important strategic target for Chinese firms. Comparing with other ASEAN countries, Thailand has much more comparative advantages in many aspects, which are much more than these 6 aspects presented by the researchers in this study. Absolutely Thailand is the priority for Chinese firms to invest rather than other countries. At the same time, many firms just wanted to seek an export platform with good export facilities and the local market may not their main target market at the first stage of investment. Many of these firms may care less about local issues.

2) Chinese culture has great impact on Chinese firms' FDI decision-making in Thailand. From the findings, more than 50 percent of respondents chose personal connections as their source of information to indentify investment opportunities in Thailand rather than using marketing research or feasibility study. The researchers inferred that "Guan xi" played a very important role in Chinese FDI. Many investors got more indirect information about Thailand rather than the direct information. When facing the limited sources of information, Chinese firms preferred to believe the real experience or indirect information from their friends.

3) The ownership and scale of parent company in China have influence on decision-making of Chinese FDI. For some firms supported by private-owned parent company, especially SMEs (small and medium enterprises), many of them may be expertise in export, but most of them have no or less experience on FDI. Because of high risks and uncertainties, FDI is much more complex and difficult than purely export. Some of them may have not recognized the importance of each aspect of the investment climate that will have an impact on their investment in the long run. Experiences or information from personal connections may be biased because of the diversity of situation and information in different businesses and industries. For some firms which are controlled by state-owned parent company in China, or some special projects highly protected by both of Chinese and Thai government, as the strong protectionism of home and host country, they seem not to care much about the macro investment environment because many of them are monopolized businesses.

\section{RECOMMENDATIONS}

Recommendations are given in 2 parts. The first part is for the Board of Investment of Thailand and the second part is for related government sectors of Thailand as follows;

\section{A. Recommendations for the Board of Investment of Thailand}

1) Maintain and create good relationship with Chinese firms or related associations in Thailand. Based on the findings, more than half of Chinese investors preferred to believe the real experience and investment information from their friends and relatives who are in Thailand. If BOI can maintain and build a good relationship with Chinese firms in Thailand, utilizing the "word-of-mouth" marketing strategy, these existing Chinese firms will be the intermediaries and presenters to bring more Chinese firms to invest in Thailand, who maybe their friends' firms or their suppliers. This is the easiest way to let more Chinese firms to access investment information about Thailand efficiently and effectively. Simultaneously, BOI can get a good connection with the commerce association of Chinese enterprises in Thailand; hundreds of Chinese enterprises are the member in this association. From this association, BOI can easily access to other non-BOI Chinese firms and have good communication with them. It is a good way to keep good relationship or communication with most influential Chinese firms in Thailand, and help more Chinese companies to know and update more new FDI incentives of BOI, not only help more Chinese firms to develop in China, but also help BOI have chances to attract more Chinese FDI.

Moreover, diversifying the information channels to attract more Chinese FDI is also recommended. There are just 3 BOI offices in China's big cities: Beijing, Shanghai, and Guangzhou. But China is so big, there are abundant of stateowned or private enterprises covering every province of China. Each province has different cultures and economic situations; it is really hard for these 3 BOI offices to reach more potential investors in other areas of China.

BOI can launch more advertising campaigns to promote Thailand as an ideal investment destination. Under some special events, BOI can get cooperation with Tourism Authority of Thailand's offices in China to do co-marketing not only to promote Thailand's amazing tourism but also to offer the favorable investment opportunities. At the same time, all the Thailand FDI in China can help BOI to promote 
investment opportunities in Thailand, all of these Thai firms can help to build good relationship with Chinese government, organizations, and many Chinese companies.

CP group, Thailand's largest agriculture-based conglomerate group of companies, is a very good example. As the long development history of $\mathrm{CP}$ in China, $\mathrm{CP}$ has created a good reputation in China's market and has kept a good relationship with Chinese government and stakeholders in China for decades. CP Group is an efficiently facilitator for the cross-border investment between China and Thailand. As many companies obtained a lot of valuable investment information or opportunities from CP before conducting FDI plans in Thailand, even some of companies directly make joint-venture investment with CP group in Thailand. Believe that there are many other Thai firms can do a good job as well as CP to facilitate the Chinese FDI in Thailand.

2) Relax some labor regulations. Regulations about labor issues are the biggest problem for production-based Chinese firms, especially in the industrial park, such as: Rayong province and Chonburi province. As the high concentration of factories from foreign countries and the inefficiency of the labor force, many factories can't find enough labor force to maximize their production capacity. At the same time, the high turnover rate of labor force also seriously affected the daily production outcome.

In order to protect Thai labor force, BOI regulates that all BOI promoted projects or firms are not allowed to hire foreign labor force from Myanmar, Laos, Cambodians, and so forth. This problem has decelerated desires of foreign investors to expand their investment in Thailand. BOI can consider to partly opening some legal foreign labor force from neighboring countries to fulfill the tasks of production level. Proper competition can lead local labor forces to improve themselves' education and skill level.

3) Offer attractive FDI incentive. Many non-BOI enterprises can't enjoy any FDI privileges or incentives, these firms perceived they were treated by Thai government unfairly and discriminately, BOI of Thailand should give some basic FDI incentives or privileges to many of non-BOI enterprises in Thailand, How much the privileges and incentives can provide to them should depend on how much benefits or welfares of these projects and industries can bring to Thailand. As many limitations, not all the Chinese FDI can get BOI's approvals, but many of these FDI players in Thailand can contribute a lot for the development of Thailand. They are deserved to enjoy some FDI incentives which may not as much as BOI promoted projects or firms have, but at least can enjoy some basic FDI incentives.

\section{B. Recommendations for Other Related Government Sectors of Thailand}

1) Improve education system and quality. Education is one of the most important soft infrastructures can support the development of one country. As the serious shortage of skilled technicians and engineers in highskill level in Thailand, Thai government should focus on the development of universities and vocational schools, providing more opportunities for Thai students to get higher level education. Particularly, Thai government should put more efforts to develop the education facilities in the up countries both in lower level and high level education. Most of good schools are highly concentrated in Bangkok, but there are limited chances for most students in the up countries to get good quality education. At the same time, many factories are concentrated in up countries, which provide good job opportunities for local people but also caused big problem for the investors as the shortage of labor force both in high and low level in the up countries.

2) Enhance infrastructure in Thailand. Thailand possesses strategic location advantages in Southeast Asia. It has great potential to be the logistics and business center of this area if Thailand can enhance both of the soft and hard infrastructure constructions quickly. The soft infrastructures include advertising agencies and media outlets that facilitate corporate communication, market research companies and logistics consultants that assist the supply chain management. Hard infrastructure, such as roads and bridges, especially, the railway networks of Thailand should be improved as one of main inland transportation tool. Increasing the coverage rate of internet nationwide can help to improve the working efficiency of whole country.

3) Relax some immigration rules and regulations. From the comments of many Chinese investors, the researchers realized that many companies complained that the 4:1employment ratio between foreign and local labors is largely limited the development of many Chinese firms in Thailand, particularly, Hi-tech industry and the startup stage of production-based factories seriously affected by the quota limitation to bring people from parent company. The different quota limitations should be applied in different industries with different organization structure.

\section{REFERENCES}

[1] J. H. Dunning, "Some antecedents of internalization theory," Journal of International Business Studie, vol. 34, no. 2, pp. 108-115, 2003.

[2] R. Gilpin, Global Political Economy: Understanding the International Economic Order, Princeton, NJ, Princeton University Press, 2001, pp. 383-399.

[3] S. Hymer, The International Operations of Nations Firms: A Study of Foreign Direct Investment, Cambridge, MLT Press, 1976.

[4] Investment Report, Various Issues, United Nations, New York and Geneva, 2003.

[5] S. Thanyakarn, "The Determinants of FDI and FPI in Thailand: A Gravity Model Analysis," Ph.D. Dissertation, Lincoln University, New Zealand, 2008.

[6] R. E. Lipsey, "Home and host country effects of FDI," presented at ISIT Conference on Challenges to Globalization, Liding, Sweden, 2002.

[7] Nagesh Kumar, "Investment on the WTO Agenda: A developing countries perspective and the way forward," presented at Cancun WTO Ministerial Conference, Cancun, Mexico, 2003.

[8] L. Nachum, "International business in a world of increasing returns," Working Paper, no. 224, ESRC Center for Business Research, University of Cambridge, 2002.

[9] J. H. Dunning, Multinational Enterprises and the Global Economy, Wokingham, England, Addison-Wesley Publishing, 1993.

[10] S. Boonlua, "A comparative analysis of the US and Japan FDI in Thailand," Journal of Academy of Business and Economics, vol. 11, no. 3, 2011.

[11] Y. Luo, "Toward a cooperative view of MNC-host government relation: building blocks and performance implication," Journal of International Business Studies, vol. 32, no. 2, pp. 401-420. 
[12] T. Yamane, Statistics, An Introductory Analysis, 2nd ed., New York: Harper and Row, 1967.

Xiao Ling Huang got a master degree of management program in international business from Chulalaongkorn Business School, Chulalongkorn University. She received a bachelor degree majoring in tourism in Thai Language from international student exchange program in model $2+2$ of Yunnan Normal University in China and Suansunandha Rajabhat University in Thailand.

Athapol Ruangkanjanases is a faculty member at the Department of Commerce, Chulalongkorn Business School, Chulalonglorn University. He received his Ph.D. degree from Illinois Institute of Technology, USA.
Before joining Chulalongkorn University, he was a full-time faculty member at School of Management, Marist College, New York, USA.

Chenin Chen is an adjunct associate professor at Chulalongkorn Business School, Chulalonglorn University. He received his D.B.A. degree from United States International University, California, USA. He is the managing director of Rayong Wire Industries Public Company Limited. He is also sitting as the board director of Capital Engineering Network Public Company Limited and UaWithya Public Company Limited. All are listed companies. 